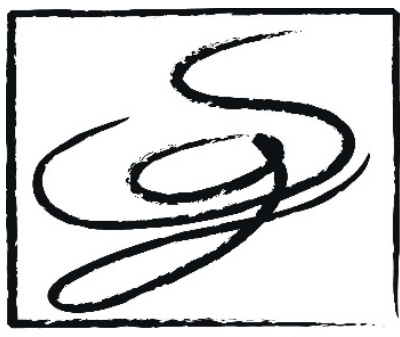

SEMIMARIO DE INUESTIGACIÓN DE GÉNERO Y ESTUDIOS GULTURALES

\section{Geas: Mujeres que Estudian la Tierra de Rosa María Mateos, Ana Ruiz Constán (Asociación de Servicios de Geología y Minería Iberoamericanos, Federación Europea de Geólogos), 2021.}

\author{
Amalia Vahí Serrano \\ Universidad Pablo de Olavide, de Sevilla \\ avahser@upo.es
}

Fecha de recepción: 02/06/2021 Fecha de evaluación: 01/09/2021

Fecha de aceptación: 07/09/2021

Desde sus orígenes, el ser humano se ha sentido atraído por los interrogantes que esconde esa esfera achatada que se ve como un punto azul desde el espacio (...) así comienza la recopilación de Rosa M. Mateos y Ana Ruiz Constán en GEAS. Mujeres que estudian la Tierra (2021) con textos ilustrados por Nívola Uyá. En tiempos como los actuales, en que la cuestión de género se sigue abriendo a nuevos debates sobre logros, balances, diversidad, etc. el papel de la mujer sigue siendo objeto de atención mayoritario en tanto que persiste una reivindicación en clave dialéctica sobre el ser productivo, productor y reproductor. En tal contexto, las autoras mencionadas -geólogas y divulgadoras científicas- publican el proyecto con un sentido pedagógico y característicamente intencionado en esta temática, aún más cuando persisten todavía más sombras que luces en torno a las condiciones individuales y los logros (sociales, intelectuales) de la mujer de hoy.

$\mathrm{Ni}$ crisis económicas ni pandemia han conseguido cerrar estas ventanas (foros de debate, publicaciones, exposiciones, cine, etc) por las que se hacen visibles las mujeres científicas. Baste mencionar, por ejemplo, solo en nuestro país y en fechas recientes, que en una ronda rápida en medios digitales encontramos el sitio Mujeres con ciencia, 0 eventos realizados con exposiciones tan evocadoras como Geógrafas y Ciencia, y una más, aquella otra de Científicas de Letras ${ }^{1}$. No solo científicas sino mujeres de todos los sectores mantienen la acción y el

\footnotetext{
1 https://mujeresconciencia.com/

https://cultura.ua.es/es/exposiciones/geografas-y-ciencia.html

https://lletres.ua.es/es/cultura/cientificas-de-letras-dia-de-la-mujer-y-la-nina-en-laciencia.html
} 
mensaje de relectura histórica que descubre su papel activo como grupo determinante.

En GEAS... encontramos una publicación amena y estimulante que, aun siendo breve, tiene el don de despertar interés para conocer mejor a las protagonistas. La recopilación podría parecer destinada a un público muy joven al que los textos imbricados con sus respectivas ilustraciones pueden resultar de la máxima expresión, pero, sin duda, atrapa la curiosidad de quien se asome sea a la edad que sea: el libro encierra justamente ese propósito y no otro. En sus páginas vierte la caracterización de doce mujeres siguiendo un mismo esquema, que parte de los aspectos personales (familia, educación, ...), para continuar ineludiblemente el relato del modo en que cada una de estas mujeres llegó a sumergirse en el campo científico; cada capítulo concluye con el desarrollo/aportación científica de la protagonista.

Si bien el título invita a encontrar una recopilación de especialistas en diferentes ramas del conocimiento de la Tierra, la inmediata presentación de las autoras aclara los motivos y el objetivo de una divulgación que induce a saber más, a buscar datos, nuevas lecturas al respecto. El patrocinio corporativo y la accesibilidad a los textos que crean sus autoras obtiene por resultado una publicación ágil y atractiva que llega incluso a saber a poco. Extraen para la ocasión doce ejemplos que ordenan cronológicamente para presentarlas al lector: Mary Anning, Florence Bascom, Inge Lehmann, Marguerite Thomas Williams, Dorothy Hill, Mary Leakey, Mareta Nelle West, Marie Tharp, Carmina Virgili, Maria Fernanda Campa Uranga, Katia Kraft y Kathryn Dwyer Sullivan.

Como referencia en el punto de partida (Anning nace en 1799) Europa y el nuevo mundo dejaban atrás un Siglo de las Luces, el XVIII, con aportaciones científicas y tecnológicas sustanciales que nutrieron la primera revolución industrial; sin pretender abrir una línea discursiva en paralelo, es preciso traer a colación que, no por casualidad Mary Wollstonecraft, nacida e incomprendida en aquellos momentos, deja en sus escritos el germen de una reivindicación y una concepción como el feminismo, que aún estaba por formularse y desarrollar. En tanto que se superaban apenas algunos dogmas y prejuicios, Wollstonecraft no llegó a conocer sus frutos, pero sentó la base para el reconocimiento social del intelecto y el alma de la mujer, y puede que quepa reconocer algunos matices de esta escritora deslizándose por el desafío que vinieron aceptando nuestras doce científicas.

Con un lenguaje sencillo y accesible para todas las edades, Geas. Mujeres que Estudian la Tierra comienza con Mary Anning, considerada la primera paleontóloga conocida del mundo occidental. Al igual que ella, otras mujeres que aparecen en la selección impulsaron el conocimiento desde una posición claramente desventajosa al sumarse las circunstancias familiares de partida a un contexto social nada amable ante ellas; bien por las circunstancias socioeconómicas familiares, bien por el rol asignado en el entorno social, algunas de estas mujeres -y muchas otras mujeres como estas- no tuvieron un camino fácil viéndose obligadas a demostrar que los 
hallazgos les correspondían a ellas en lugar de a sus mentores a los que la sociedad les resultaba fácil otorgar reconocimiento.

Sobre las semblanzas que aparecen en el libro se detectan algunas diferencias sobre las circunstancias que les favorecieron o dificultaron introducirse en el campo de la Geología; mujeres como Bascom, Lehmann o Leakey pudieron acceder sin gran complicación como investigadoras científicas en tanto que procedían de entornos familiares que lo propiciaron, pero no fue así en otros casos mencionados, sirva de ejemplo de Marguerite Thomas Williams. Esta norteamericana abrió una vía decisiva en la definición del Antropoceno hace más de 60 años y a poco que nos asomemos a sitios web con "Antropoceno" como motor de búsqueda comprobaremos que se omite por completo su mención en beneficio de algunos colegas contemporáneos. Por otro lado, hay en la selección quien -como Nelle West, Tharp o Dwyer Sullivan- trabajaron directamente al servicio directo de las instituciones políticas y, si bien no ocupaban de hecho puestos relevantes, consiguieron vencer prejuicios defendiendo sus postulados, principios y experimentos hasta dejar patente la validez de sus hallazgos.

En relación con las diferentes derivas de la mujer y el trabajo intelectual, no solo en el mundo de las ciencias, hubiera cabido esperar una progresión geométrica en su incorporación al campo de las Experimentales, al igual que a las Ciencias Sociales y las Humanísticas; sin embargo, el balance actual del reconocimiento y las aportaciones hace necesaria una revisión profunda de la concepción de la participación de la mujer en el mundo científico. Sin ir más lejos, pongamos como ejemplo los resultados de una encuesta de la Sociedad Europea de Oncología Médica, cuyo informe recientemente publicado arranca con un titular desalentador Menos investigación y peor calidad de vida: la brecha de género se agrava para las oncólogas en la pandemia ${ }^{2}$. No es una novedad y no es solo en el campo de las ciencias, pero es concluyente, las circunstancias adversas para la sociedad incorporan un sesgo mayor en el caso de las mujeres, por eso urge esa revisión a la que antes se aludía para incorporar mayores garantías en las condiciones laborales de las mujeres a todos los niveles.

Publicaciones como la que nos ocupa contribuyen en mayor o menor medida a reducir las distancias, no restan, pero han de llegar cargadas de intención y expresión, es decir, no dar por sentado el conocimiento y la difusión sino persistir en la educación y la sensibilización. En plena Postpostmodernidad, la era tecnológica deja al descubierto que ni los modelos democráticos más maduros han superado los escollos en materia de políticas sociales y de igualdad pese a los esfuerzos por instaurar marcos normativos, políticas, planes y programas en esa dirección. En nuestra opinión es, cuanto menos, razonable dudar de algunos aspectos que atañen al reconocimiento y la profesionalización de la mujer actual en el campo científico. En el marco de los países de la OCDE en que tantos estudios y estadísticas siguen evidenciando la brecha salarial y el sesgo de

2 https://www.agenciasinc.es/Noticias/Menos-investigacion-y-peor-calidad-de-vida-labrecha-de-genero-se-agrava-para-las-oncologas-en-la-pandemia $\quad 25 / 05 / 2021$ ) 
género en determinados sectores, llama poderosamente la atención la renovada presencia de hombres en las cúpulas y puestos de decisión.

Sin entrar en un enfoque de género más pausado, que hubiera requerido mayor detenimiento, concluimos que el libro reseñado presenta de modo intencionado la fotografía individual de cada una de las mujeres elegidas para la ocasión. Ahondar en las razones y en las dificultades que pudieron encontrar éstas y sus predecesoras en el camino de la ciencia ha de ser objeto de otros espacios y de hecho, la Sociedad Geológica de España alberga una Comisión específica dedicada a la divulgación de todo cuanto acompaña a las profesionales en tanto que mujeres de su tiempo. Sobre las protagonistas cabe decir que todas en mayor o menor medida se enfrentaron a lo desconocido, una auténtica odisea del saber. Como si se tratara de una publicación urgente, ésta nos sitúa ante una porción de mujeres rompedoras más allá de la Geología cuya semblanza invita a preguntarnos más y más. 